

Business \& Social Science IJRBS

\section{Research in Business and Social Science}

IJRBS Vol 7 No 4, ISSN: 2147-4478

Contents available at www.ssbfnet.com/ojs

\title{
Influence of Perceived Service Quality on Consumer Satisfaction amongst Dairy Milk Processors in Kenya
}

\section{Anne Wairimu Mwangi}

Department of Business and Entrepreneurship, Karatina University, Kenya

Ndung'u Kabare

Department of Business and Entrepreneurship, Karatina University, Kenya

\section{Kenneth Wanja}

Department of Business and Entrepreneurship, Karatina University, Kenya

\begin{abstract}
In today's competitive retail market, as service quality improves, the customer's expectation and lateral demand on service level is increased from time to time. Dairy milk processing firms in Kenya are struggling to get it right in providing service quality. This has created dissatisfied consumers and this has led to merging of some dairy milk processing firms and loss of jobs due to closure of some dairy milk processing firms. Therefore, this study aimed at filling this knowledge gap by examining the influence of perceived service quality on consumer satisfaction amongst dairy milk processors in Kenya. The study was guided by cross-sectional research design. The study population comprised of consumers who purchase processed dairy milk from major supermarket chains in Kenya. Primary data was collected from 384 respondents using a semi-structured questionnaire which was selfadministered. Descriptive statistics and regression analysis were used to analyse data with the help of SPSS version 21. The results showed a positive and significant relationship between the perceived service quality and consumer satisfaction. Respondents indicated that, perceived service quality was consistent to their satisfaction. The findings showed that, consumers of dairy milk products had a high rating of service quality offered to them by dairy milk processors hence high satisfaction levels. The study therefore concluded that, perceived service quality is an important predictor of customer satisfaction. Milk processors must therefore strive to match and even exceed their customer's productservice quality with what customers expect.
\end{abstract}

Key words: Perceived Service Quality, Consumer Satisfaction and Dairy Milk Processors JEL classification: M31 


\section{Introduction}

The dairy milk industry is facing a very competitive environment that is forcing them to enhance the development and sustainability of loyalty opportunities (Davis, Dong, Blayney \& Owens, 2010). Due to the fierce competition, keeping loyal customers is an important strategy for achieving distinct and sustainable competitive advantage (Roberts, 2003). As the competitive environment turns out to be more powerful, the most essential issue the manufacturers confront is to give good quality products or services, yet keep steadfast shoppers who will contribute long term benefits to the manufacturers (Tseng \& Seidman, 2007).

Globally, products and services by the milk industry represent a significant contribution to the economy. Milk and milk products consumption is common throughout the world. The dynamics that affect milk production tend to differ from country to country (Nyariki \& Thirtle, 2000). Dairy milk processors have been a source of employment to many people globally. In Ethiopia, there are 24 processing units which have created employment opportunities in rural areas, with each unit employing up to four permanent workers (Redda, 2001). In Denmark, Arla foods is a dairy company and a cooperative owned by over 7000 Danish and Swedish dairy farmers. Arla's core markets are in Sweden, Denmark, Finland, United Kingdom (UK), Germany and Netherlands. The company has made a lot of investment in ensuring quality in their products by training employees on how to handle critical incidents on dairy, hygiene and food safety as well as packaging their products well for safe delivery to the customers (Martins, 2010). In New Zealand, Fonterra Cooperative Group takes milk to its approximately 13,000 farmers, representing $96 \%$ of raw milk produced and delivering most of it to consumers in export markets worldwide (Fonterra,2011). The company is in control of activities that range from producing milk products, to distributing end products in retail markets (Graham, 2014). It's packaging of products, quality control of the products, transportation and freight forwarding have all been integrated, hence making the practices of the cooperative more effective. Fonterra Cooperative Group keeps tight control over the raw ingredients and products which mainly include fresh milk which is exported worldwide (Fonterra, 2011).

A study in United States of America (USA) by Wolfe and Shepherd (2006) and Wolfe and Best (2005) concluded that it is essential to decide the item utilization, buy recurrence, holder inclinations, buy area, milk and milk products costs, probability to buy milk and milk products, buy inclination and cost, and item highlight appraisals. Germany has the largest number of milk processors that are relatively large. In 2009 Nordmilch Konzern was the biggest one processing 4.1 million tons (Hemme, 2014). The ten biggest processors account for 58 per cent of the total milk delivered in Germany.

In Kenya, the dairy industry contributes $14 \%$ to the agricultural gross domestic product and $4 \%$ to the overall Kenya gross domestic product (GDP) and is a major source of livelihood for more than one million people in the sub-sector (Mutura, Mwangi, Nyairo \& Wambugu,2016). In 2016, South Africa milk producers earned R15,660 million from milk production, which was $9.1 \%$ more than the previous year, which accounted to a GDP of 2.1\% (Department of Agriculture, Forestry and Fisheries, 2016). Yilma, Guernableich \& Sebsibe (2011) says that Ethiopia livestock and livestock products contribute about $9.1 \%$ of the country's total export earnings with a value of about 182 million US Dollars. Dairy industry in Uganda contributes about $9 \%$ of the country's GDP (Ekuou, 2014). In Rwanda, the dairy sub sector contributes $15 \%$ to Agricultural Gross Domestic Product (AGDP) and 6\% to GDP (Bendito \& Twomlow, 2014). In Tanzania, dairy industry contributes about one-third of $4.6 \%$ livestock industry contribution to the GDP (Kurwijila, 2010.).

In Kenya, currently the sector provides food, income and employment for approximately 1.8 million people across the dairy value chain: farmers, transporters, traders and vendors, employees of dairy societies, milk processors, input suppliers, service providers, retailers and distributors (Ettema, 2012). The dairy sub sector contributes to large number of people who are engaged throughout in the dairy milk value chain and nutritional well-being of many rural communities (Mutura et al., 2016). In Kenya, an estimated $80 \%$ of the 5 billion liters of milk produced annually is supplied by small holder dairy farmers while $20 \%$ of the remaining amount of 1 billion is supplied by large scale dairy farmers (Odero, 2017). Within this amorphous group of small holders dairy farmers an increasing number is commercializing fast and practicing dairy farming as their core business (Odero, 2017). In terms of nutrition and food security, almost all Kenyans consume milk on a daily basis with an average per capita milk consumption of 115 litres per year [Kenya Dairy Board (KDB), 
2014]. Dairy products make up the largest share of food expenditure in Kenyan household budgets (Njagi, 2013). Due to the importance of the dairy industry in Kenyas' growth and development it has been recognized in Vision 2030 (Baiya \& Kithinji, 2010).

The dairy processing industry in Kenya is dominated by a few big processors and a high number of smaller and medium operators. The formally licensed dairy processors in Kenya are 40 dairies that actively produce and avail products through normal retail channels (KDB, 2014). Latest figures show that there are 4 big dairies processing above 100,000 liters per day. These dairies include Brookside, New KCC, Sameer Agriculture and Livestock and Githunguri Dairy Cooperative Society. Other medium level dairies processing less than 100,000 litres per day but with a significant intake include Kinangop Dairy, Meru Dairy Cooperative Society and Kabianga Dairy (KDB,2014).

Service quality has its underlying foundations in the business and administration field. Service quality is a standout amongst the most essential structures in service marketing, because of its last impact on clients' rehashed buys, and those unwavering clients who buy over and over are considered as the base of any business (Caruana, 2002). Marketers have understood that, to hold clients and to help showcase development, processors must give superb administration (Dabholkar, Shephard \& Thorpe, 2000; Zeithaml, 2006). In Kenya, for dairy milk processing industries to remain competitive locally and globally they must create value by having high quality products and variety, perceived value and satisfied consumers in order to create a sustainable loyal consumer base (Karanja, 2007).

\section{Statement of the Problem}

Absence of product service diversification and limit with respect to value addition by Kenya dairy processors has prompted a large amount of milk produced by farmers to be consumed raw. (Kariuki, 2016). In the present aggressive retail market, as perceived service quality enhances, the client's desire and lateral demand on administration level is expanded every now and then (Ghosh, Tripathi \& Kumar, 2010). Absence of high quality service by milk processors has hosed firms' intensity prompting loss of milk and milk products (Graham,2014). Superville and Gupta (2001) places that for firms to be fruitful they should will enhance nature of items and quality administrations in understanding to purchaser's request. Absence of value items and perceived service quality by milk processors in Kenya has led to disappointed purchasers and the final products are non-productivity, making mergers and loss of employments (Olorunniwa, Hsu \& Udu, 2006).

In Kenya, scholars have written a lot on primary production stage in the dairy milk industry. Tuei (2010) did a study on "Milk Quality Control and Regulation in Dairy Production: A Case of Dairy Production in Kikuyu Division, Kenya". The study found out that, to enhance milk quality smallholder ranches need to benefit new structure of tanks for little measures of milk for transporting milk to the required goal. Kiplangat (2015) did a study to examine the existing supply chain management in Kenya's dairy industry using Gakindu Dairy as a case study. The study found that dairy ranchers sold their milk through the casual chain mostly on the grounds that it offered higher costs and quality than the formal chain. At secondary production stage, a study by Mwendwa (2008) on establishment of strategic responses by Kenya milk processors to environmental challenges. The study found that, firms have created methodologies to counter respond to the effect of the ecological powers. Njarui, Gatheru, Wambua, Ngulu, Mwangi and Keya (2012) did a study whose objective was to understand the functioning of milk processing and marketing systems in order to identify appropriate interventions to enhance growth of the dairy industry in eastern province, Kenya. They found that to stay aggressive, dairy milk processors must broaden their items through esteem expansion and savvy techniques. In view of the mentioned studies, it is clear that, a study that relates perceived service quality is yet to be done. Therefore, this study aimed at filling this knowledge gap by examining the influence of perceived service quality on consumer satisfaction amongst dairy milk processors in Kenya

\section{Purpose of the Study}

To determine the influence of perceived service quality on consumer satisfaction amongst dairy milk processors in Kenya. 


\section{Hypothesis}

$\mathrm{H}_{01}$ - Perceived service quality has no significant influence on consumer satisfaction of dairy milk processors in Kenya

\section{Literature Review}

The idea of service quality ought to be by and large drawn closer from the client's perspective since they may have distinctive qualities, diverse ground of evaluation and distinctive conditions (Chang, 2008). Advertisers understood that, to hold clients and to help showcase development, they should give high caliber of services (Dabholkar, Shephard \& Thorpe, 2000; Zeithaml, 2006). Services are progressively turning into a bigger segment of numerous associations' territorially, broadly, and all-inclusive and are considered as an instrument for income streams.

Parasuraman, Zeithaml and Berry, (1985) proposed a scale called SERQUAL which is a conventional estimation device that has been used broadly in surveying service quality in a wide assortment of service settings. The model distinguished 97 characteristics which were condensed into ten measurements. These measurements were found to affect service quality and were viewed as the criteria that were essential to get to client's desires and recognitions on conveyed benefit (Kumar, 2014). The SERVQUAL scale which is otherwise called the Gap Model by Parasuraman, Zeithaml and Berry, (1988) has been ended up being a standout amongst other approaches to quantify the quality of services gave to clients of handled dairy drain. This administration assessment strategy has been demonstrated steady and dependable by a few creators (Brown, 1993). Jain and Gupta (2004) held that, when perceived or experienced service is not exactly the expected service, it suggests not exactly acceptable service quality, and when seen benefit is more than anticipated services, the undeniable derivation is that service quality is more than agreeable

From the manner in which SERVQUAL hypothesis is exhibited, it appears the thought best fits the assessment of service quality from the prepared dairy milk buyers point of view. This is on account of when it is expressed "seen" and "expected" benefit, it is certain this goes to the individual, who is going to or is expending the administration; who unquestionably is the buyer. The thought was that, processed dairy milk shoppers make benefit assessments dependent on the specialized measurement that is what is conveyed and on the practical measurement that is the means by which, why, who, and when it is conveyed (Laroche, 2004: Grönroos 2007). In spite of the fact that the components recorded in SERVQUAL demonstrate have been ended up being the fundamental strategy for assessing administration quality from the customer's point of view (Brown, 1993), downsides in utilizing SERVQUAL in estimating administration quality has been the reason that the SERVQUAL scale was proposed by Cronin and Taylor (1992) referred to in Jain and Gupta (2004) after they raised doubt about the theoretical premise of the SERVQUAL, having discovered it, prompted disarray with administration fulfillment.

The present information concentrated administrations organizations require solid techniques for estimation, evaluation, and enhancement (Spohrer \& Maglio, 2008). Service quality is controlled by figuring the distinction between two scores where better administration quality outcomes in a littler hole (Landram, 2008). The ideas of service quality and consumer service satisfaction have been exceedingly considered and utilized in promoting writings and exercises, for quite a long time. The connection between administration conduct and administration quality has demonstrated its job and significance in administration/showcasing (Heskett \& Sasser, 2010; Hutchinsona, 2009).

Consumer loyalty is a key factor in development of client's wants for future buy (Mittal et al., 2001). Seen service quality isn't just engaged with the last item and administration, yet in addition associated with the creation and conveyance process, in this way representative inclusion in process overhaul and responsibility is critical to deliver last items or administrations (Kumra, 2008). An examination led by Sureshchandar, (2002) demonstrates that, there is a two-path connection among SATISFACTION and service quality. As demonstrated by Thomson, (2002), the service quality schools see fulfillment as an ancestor of administration quality, which is a satisfaction with various individual exchanges falling into a general mentality towards service quality. An examination by Oliver (2009) proposes that both service quality and customer satisfaction are two unmistakable however related builds. It is especially valid for the administrations firms where 
expanded level of customer satisfaction results in benefit expansion. Banerjee and Sah (2012) examined the connection between service quality, esteem, satisfaction and social aims in the general population segment bank in India and the outcomes expressed that administration quality was found to fundamentally impact customer satisfaction and esteem observations. The currents study therefore examined the influence of perceived service quality on consumer satisfaction amongst dairy milk processors in Kenya Figure 1 shows the variables and their indicators as used in the study

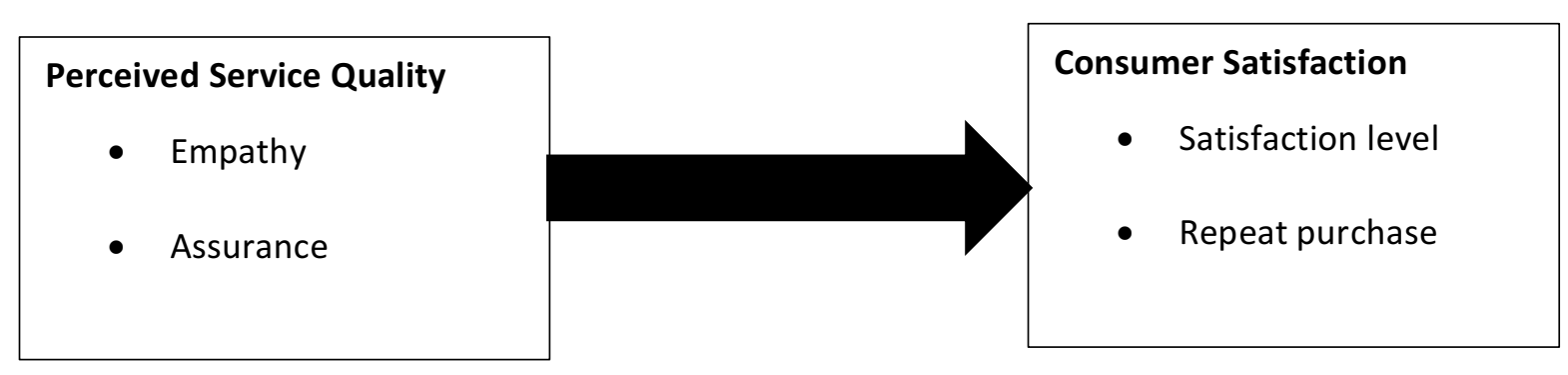

Figure 1: Conceptual Framework

\section{Research and Methodology}

The study adopted a pragmatic research philosophy. Pragmatism is relevant particularly where the research question does not suggest clearly that either a positivist or interpretive philosophy should be adopted in an inquiry. A combination of positivism and interpretivism should be combined to address a social real life issues (Creswell \& Plano, 2011). Cruz (2015) used pragmatism philosophy in his study of relationship between service quality and customer satisfaction. This study was guided by cross-sectional research design. Cooper and Schindler, (2011), posited that research design enables the researcher in the allocation of limited resources by posing crucial choices in methodology. This study used mixed method approach which combines elements of qualitative and quantitative research approaches (Johnson, Onwuegbuzie \& Turner, 2007). Its use allows the researcher to compensate for the weakness of using a single approach, and take advantage of the strengths of the other in order to achieve best results (Creswell \& Clark, 2011).

The study population comprised of consumers who purchase processed dairy milk from 15 major supermarket chains in Nairobi, Nakuru, Eldoret and Mombasa. The study collected data from fifteen (15) major supermarkets in Nairobi, Nakuru, Eldoret and Mombasa. A sample of 384 respondents was calculated using Cochran (1977) formula. The respondents were drawn from consumers who buy processed dairy milk from major supermarkets in Nairobi, Nakuru, Eldoret and Mombasa and were selected using simple random sampling. Simple random sampling was used because each population element had a known and equal chance of selection.

This study adopted a self-administered method in distributing the questionnaires. This is because selfadministration of the questionnaire is cheaper, quicker and is above researcher's effect and variability. It is also highly convenient for the respondent as they could fill them during free time or when workloads are manageable (Hawker \& Rowe, 2008). A pilot study was carried out by pre-testing the questionnaire of a selected sample which was similar to the actual sample to be used in the study. For pilot testing, data from 30 respondents was collected, representing $10 \%$ of the population in the study. The procedure that was used to pre-test the questionnaire was identical to that which was used during the actual data collection to allow meaningful observation. Cronbach's alpha coefficient was used in measuring internal consistency of the questionnaire. Cronbach's Alpha statistic ranged from 0.8 to 0.9 , indicating high reliability of data. Mertens (2010) avers that the closer the coefficient is to 1.0, the more reliable the measurements. This study used convergent validity and discriminate validity. In this study, multiple outliers were tested using mahalanobis D- square. Cases with high D- square values were considered to be outliers. Normality used measure of skewness and kurtosis. Multicollinearity was measured using Variance Inflation Factor (VIF). 
Mwangi et al. / International Journal of Research in Business and Social Science,

Vol 7 No 4, 2018 ISSN: 2147-4486

Homoscedasticity was tested using Levene's test. Hypothesis was tested using t-test. Data analysis was carried out with assistance of Statistical Package Software for Social Sciences (SPSS) Version 21.

\section{Results and Discussion}

\section{Response rate}

A total of 370 out of the 384 questionnaires were filled and returned. All the questionnaires were correctly filled and were considered adequate for data analysis. This constituted a $96.4 \%$ questionnaire return rate, which is considered very good by Saunders, Lewis, and Thornhill (2009) and 'a very high response rate' by Bryman and Bell (2011).

\section{Diagnostic Tests}

Diagnostic tests for outliers, normality, linearity, multicollinearity and homoscedasticity were conducted. Testing for outliers was conducted using Mahalanobis distance. The findings showed that, there was no problem of outliers as both perceived service quality $(p=0.083)$ and consumer satisfaction $(p=0.017)$ had $p$ values above 0.001 . Perceived Service Quality had a skewness of 1.331 while consumer satisfaction had a skewness of 0.831 indicating normal distribution as the values lie between -3 and +3 as recommended by West, Finch and Curran (1995). Linear association test showed that, there was linearity in the variables as the perceived service quality $(p=0.043)$ had $p$-values less than the critical value of 0.05 as recommended by Bai and Perron (1998). In testing for multicollinearity, perceived Service Quality (VIF=11.451) and Consumer satisfaction $(\mathrm{VIF}=1.301)$ showed no multicollinearity problems as both VIF values less than 10. Levene's statistic yielded a $p$ value of 0.057 thereby satisfying the assumption of homoscedasticity as it was greater than the critical value (0.05) as recommended by Bryman (2012).

\section{Perceived Service Quality}

To assess perceived service quality respondents in the study were asked about buyer- seller interaction, quality of service, assistance from merchandisers, premium benefits and identification of firms' products. The results are presented in 1 .

Majority $(M=3.97)$ of respondents disagreed that there was good buyer-seller interaction to their satisfaction as a consumer. This is in agreement with Benton and Maloni (2005) in their study "The Influence of Power Driven Buyer-Seller Relations on Supply Chain Satisfaction" findings show how the buyer-seller relationship affects supplier satisfaction; the power-affected supply chain buyer-supplier is important in performance and supplier satisfaction. The results are however in disagreement with Jap and Anderson (2009) in their study "Testing a Life Cycle Theory of Cooperative Inter Organization Relationships: Movement Across Stages and Performance" who found that relatively higher-quality relationships tend to exhibit more friendliness, less question asking, disagreement, and compliance behavior as compared with lower-quality relationships. Buyers in lower-quality relationships tend to dominate the interaction by disagreeing and talking a larger percentage of the time relative to buyers in higher-quality relationships. As the quality of the relationship increases, however, buyers disagree less and allow sellers more latitude in time spent talking thus spreading a good word of mouth about the dairy milk products. The results show that, there was a poor relationship between the seller and the buyer. This implies that dairy milk processors in Kenya can lose business if their merchandisers sow bad blood relationships with the consumers irrespective of product quality. This will lead to a negative attitude towards the product hence affecting consumer satisfaction levels.

A moderate number $(M=2.85)$ of the respondents agreed that quality of service was consistent with their expectations. This finding is in contrast with Dheepa and Karthikeyan (2015) study on "Customer's Perceived Service Quality of Departmental Stores; An Empirical Investigation" concluded that, expectations exceeded perceptions, denoting gaps in service quality, which means that department stores do not provide the level of service demanded by customers. This finding is in agreement with Khosti (2016) in the study "Developing Service Quality" who showed that customers' expected service quality is higher than their experienced ones. Malhan (2014) in the study "An Empirical Study of Customer Expectation and Perception of Service Quality; A Case Study of Uchumi Megastores in Kenya" found that customers have higher service quality 
expectations that if not met by supermarket can result to customer dissatisfaction and losing customers to competitors. The results therefore show that perceived service quality was high according to consumers' expectations. This implies that, dairy milk processors in Kenya had developed a service quality strategy that met consumers' expectations. When consumer expectations are met, it leads to positive customer behavior that is crucial for customer retention and loyalty for dairy milk processors in Kenya.

Majority $(M=4.24)$ of respondents disagreed that merchandisers assisted consumers in the supermarket. This is line with a study done by Onyango (2011) "Improving Customer Satisfaction and Customer Service Levels" who revealed that the customers were unhappy with the services they received and indicated that there are still demands that need to be fulfilled. This is also in agreement with Rinaldi, Morabito and Tachibana (2009) who observed that quick responsiveness has an important role compared to others for the customer service level. This shows that customers were dissatisfied with the responsiveness of merchandisers. Dairy milk processors in Kenya will experience low sales as a result of dissatisfaction among the dairy milk consumers. A dissatisfied consumer will have a negative perception towards the product thus resulting to a shift to competitors' products. Dairy milk processors should know that, an excellent customer service go hand in hand with consumer satisfaction in order to promote stronger customer loyalty.

Similarly, majority $(M=4.62)$ of respondents disagreed that they were offered premiums when they bought in large quantities. These findings are in contrast with a number of studies. For example, the results of this study contrast Kumar's (2014) on "Factors Influencing Consumer Buying Behavior with Special Reference to Dairy Prpducts in Pondichery State" who concluded that customers were offered discounts and premiums when they purchase goods. The findings are also in contrast with Gilbert and Jackana (2002) in their study "The Efficacy of Sales Promotion in UK Supermarkets: A Consumer View" found that only price discount promotions proved to be influential to buying behavior of consumers. A dairy milk consumer will be motivated to buy products that are discounted and dairy milk processors should capitalize on giving premiums to consumers to create positive consumer perception towards dairy milk products thus creating brand loyalty. Offering incentives to dairy milk consumer' is a method of sales promotion that creates dairy milk brand awareness to consumers'.

Majority $(M=1.69)$ of respondents could identify firm's products using the firm's symbols and brands. The finding is in agreement with Ampuero and Vila (2006) study on "Consumer Perception of Products Packaging" concluded that consumers have exhibited harmonious perceptions towards products-packaging strategies, so one can conclude that a general feeling as to what a particular packaging exactly means exists. The findings are consistent with Biji, Ravishankar, Mahan and Gopal (2015) in their study "Smart Packaging Systems for Food Applications: A review "who found that adoption of suitable packaging technologies by the food industry can be useful to extend the shelf life, improve quality, safety, and provide information about the product. This shows that majority of respondents in the study were able to identify the milk products easily. Dairy milk consumers' in Kenya have the ability to identify symbols and brands of products of dairy milk processors in Kenya. This shows a positive attitude of Kenyan consumers towards locally processed dairy milk products. A positive identification of firm and brand image creates a positive consumer perception. This leads to positive consumer attitude and loyalty towards the product (Awan and Reheman, 2014). A positive identification of firm and brand image is a competitive advantage for dairy milk processors in Kenya. In a nutshell, dairy milk processors in Kenya should maintain and become more innovative on how they package their products. Milk products packaged innovatively helps in differentiating, market segmentation and competitiveness in the market. 


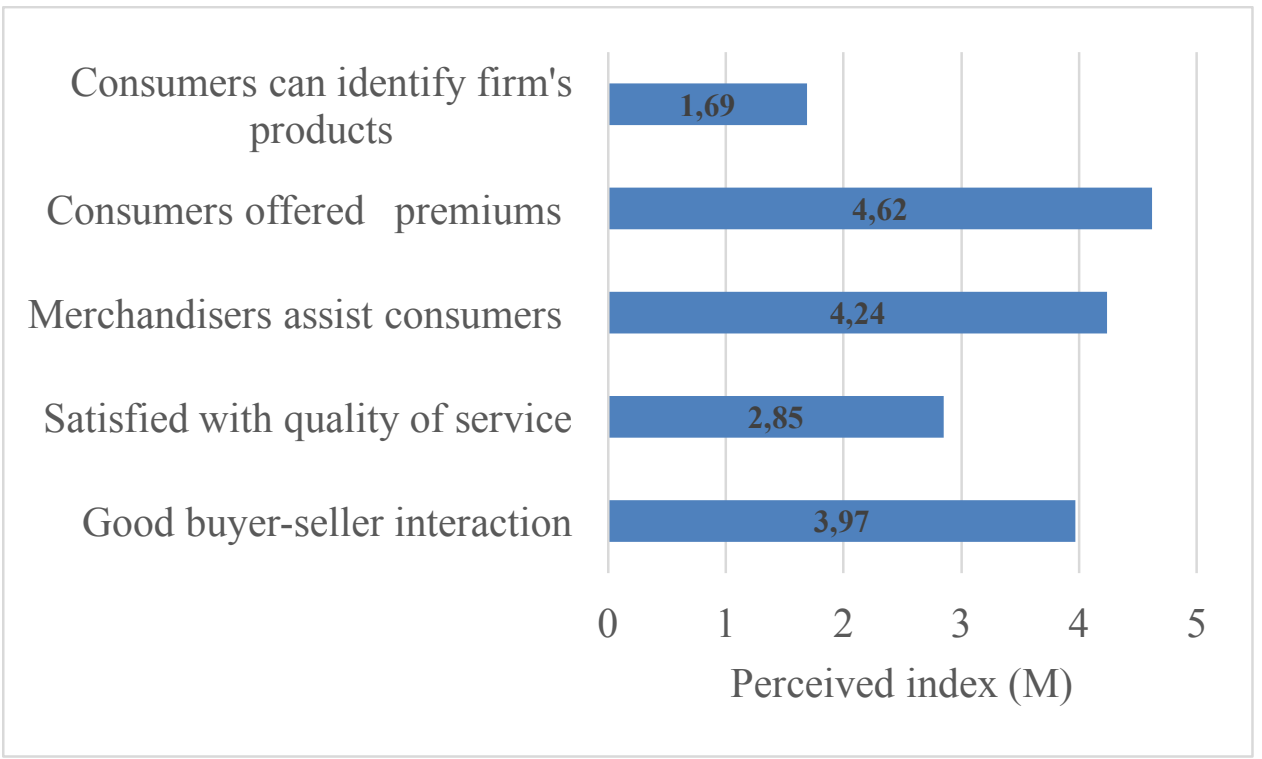

Figure 2 Descriptive Analysis of Perceived Service Quality

\section{Consumer Satisfaction}

To assess consumer satisfaction, the respondents in the study were asked about their satisfaction with quality, availability, services, complaints handling, availability, services and whether they spread word of mouth about their preferred brand. The findings are shown in Figure 2.

Majority $(M=1.46)$ indicated that they were satisfied with their preferred milk processors products. Majority $(M=1.42)$ of respondents indicated that they were satisfied with the quality of their preferred milk products. Similarly, majority $(M=2.06)$ indicated that they spread a positive word of mouth about preferred milk processors products. The results concur with a study by Abdul-Muhmin (2010)" Repeat purchase intentions in Online Shopping; The Role of Satisfaction, Attitude and Online Retailers 'Performance" whose results confirmed an overall consumer satisfaction with previous online purchases and attitude toward online purchasing on repeat purchase intentions. In turn, attitude is positively determined by overall satisfaction and negatively by experience with online purchase problems. Hsu, Chang \&Chuang (2015) in their study "Understanding the Determinants of Online Repeat Purchase Intention and Moderating Role of Habit" also found that perceived value exerts stronger effect on repeat purchase intention for high-habit customers, whereas trust and satisfaction have higher influence on repeat purchase intention for low-habit customers. The results therefore show that consumer satisfaction with dairy milk products was high. Consumer satisfaction has direct effect on dairy milk consumers' trust, commitment and word of mouth on dairy milk products therefore dairy milk processors need to maintain high quality products so as to increase their market share in Kenya. Dairy milk processors in Kenya need to build positive consumer perception by delivering superior value on existing, potential and anticipated dairy milk consumer needs through building of superior brand power.

Majority $(M=1.28)$ of the respondents agreed that they trusted that, their preferred milk product was always available in the supermarket shelves. Majority $(M=1.73)$ of respondents also indicated that their preferred milk processors products are always available to their expectations as a consumer. This is consistent with findings of Bian (2011) study "The Role of Brand Image, Product Involvement and Knowledge in Explaning Consumer Purchase Behaviour of Counterfeits" found that customer satisfaction is enhanced by product availability and vice versa. This is also consistent with a study by Shamdasani, Stanaland and Tan (2001) "Insights for Advertising Placement on the Web" who established that product availability has traditionally been believed to enhance involvement levels and consequently purchase intention. The results therefore indicate that product availability was crucial to consumers. This implies that when products are available in the market customers' will go for the products when needed thus satisfying their needs. Dairy milk processing firms in Kenya need to ensure regular availability of dairy milk products in various retail outlets so as to create trust and positive consumer perception towards their dairy milk products. Dairy milk firms should know that, 
loyal consumers are an asset to them and that it is costly to attract new consumers than maintaining the existing ones hence the need to have innovative and efficient distribution channels.

Majority $(M=1.66)$ of the respondents indicated that they were satisfied with the supermarket's services. Majority $(M=1.6)$ of the respondents agreed that they believed the supermarket offered high quality services to their satisfaction. This results are in disagreement with that of Dheepa and Karthikeyan (2015) study "Customer Perceived service Quality of Departmental Stores ;An Empirical Investigation" found that expectations exceeded perceptions, denoting gaps in service quality, which means that department stores do not provide the level of service demanded by customers. This means that customer satisfaction is rather low and that there is still room for department stores to improve on their performance. The results are also in line with Khosti (2016) study “Developing Service Quality" who concluded that customers' expected service quality is higher than their experienced ones. The results therefore show that service quality was important for customers. Unmet service quality can result to consumer dissatisfaction and loss of dairy milk consumers' to competitors. A superior consumer service provision has a positive consumer perception and builds consumer confidence by creating a strong consumer-brand relationship thus increasing the market share.

A moderate number $(M=3.1)$ of the respondents agreed that they trusted that the supermarket handles complaints effectively. This is consistent with Ateke and Kalu (2016) study "Complaints Handling and post Complaints Satisfaction of Consumers in Port Harcourt, Nigeria" that concluded that post-complaint satisfaction is influenced by complaint handling through customer-firm interaction, complaining accessibility and compensation policy. This shows that supermarkets complaints handling is important for consumers to remain loyal to a brand. It is worth noting by milk processors that if consumer complaints are not addressed in time this leads to consumer dissatisfaction and consumer disloyalty. Whether a complaint is met with an appropriate response or not has a great impact on the consumer's perception of satisfaction with the service provided.

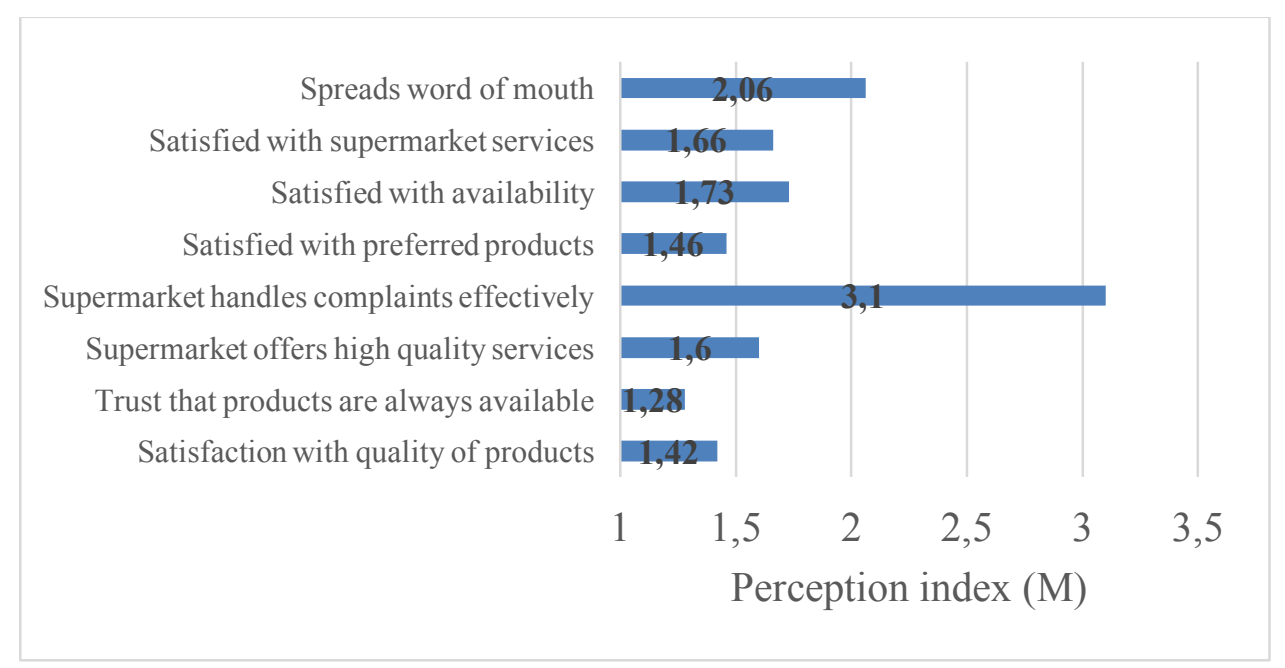

Figure 3 Descriptive Analysis of Consumer satisfaction

\section{Relationship between Perceived Service Quality and Consumer satisfaction}

Perceived service quality was measured using empathy and assurance while customer satisfaction was measured using satisfaction level and repeat purchase. Linear regression analysis of perceived product quality on individual customer satisfaction was conducted. Hypothesis was tested using t-test. Using the values in Table 1 equation 1 for perceived service quality and customer satisfaction is as follows

\section{Equation 1 Effect of Perceived Service Quality on Customer Satisfaction}

$Y=1.215+0.324 P S Q$

Where $Y=$ consumer satisfaction, $P S Q$ is perceived service quality 
The R-square was $20.6 \%$ which means perceived service quality explained $20.6 \%$ of change in consumer satisfaction. The model was correctly specified given that the $F$ statistic was significant at $1 \%(P<0.01)$. Perceived service quality was statistically significant at $5 \%$. This shows that perceived service quality has an overall effect on consumer satisfaction. The coefficient of perceived service quality was 0.324 which means a unit change in perceived service quality leads to a 0.324 increase in the level of consumer satisfaction. Perceived service quality has an overall effect on consumer satisfaction.

It is important for dairy milk processors to understand consumer needs and then deliver the best individualized quality service. In delivering a customized service, dairy milk merchandisers need to have the requisite knowledge and competence of high quality service provision in order to convey trust and confidence to consumers' satisfaction. A firm that embarks on assurance and empathy of its consumers has improved consumers' perception of its perceived service quality; this in turn makes perceived service quality a powerful competitive weapon. Dairy milk processors need to continuously offer superiority service and consistently perform above adequate service level in order to capitalize on opportunities for exceeding consumer desired service level. This automatically creates a satisfied consumer market and improved sales for dairy milk products.

Table 1: Regression Output

\begin{tabular}{|c|c|c|c|c|c|}
\hline \multirow[t]{2}{*}{ Model } & \multicolumn{2}{|c|}{$\begin{array}{l}\text { Unstandardized } \\
\text { Coefficients }\end{array}$} & \multirow{2}{*}{$\begin{array}{l}\text { Standardized } \\
\text { Coefficients } \\
\text { Beta }\end{array}$} & \multirow[t]{2}{*}{$\bar{T}$} & \multirow[t]{2}{*}{ Sig. } \\
\hline & $\bar{B}$ & Std. Error & & & \\
\hline (Constant) & 1.215 & 0.055 & & 22.00 & 0.00 \\
\hline $\begin{array}{l}{ }^{1} \text { Computed scores of perceived service } \\
\text { quality }\end{array}$ & $e_{0.324}$ & 0.035 & 0.454 & 9.242 & 0.00 \\
\hline
\end{tabular}

$R=0.454, R^{2}=0.206$, Adjusted $R^{2}=0.204, F=85.408, P=0.00$, Std. Error $=0.417$

\section{Conclusions}

The results of this study showed that, a positive and significant relationship exists between the perceived service quality and consumer satisfaction. Respondents indicated that, perceived service quality was consistent to their satisfaction. This shows that, dairy milk processors in Kenya had identified consumer service as a crucial component of their product-service strategy. A superior customer service creates and maintains goodwill of existing customers, lures back lost customers and attracts new ones. Dairy milk processors had overtime designed products support services that targeted consumers' value as a major tool towards gaining a competitive advantage. It is imperative therefore that, dairy milk processors make a decision on the service mix they offer to their customers.

Respondents also indicated that, merchandisers did not assist them in the supermarkets. Most of the merchandisers did not have formal training on customer care. This means that, dairy milk processors must invest in positively changing attitude of merchandisers, arrange for their retraining and hire well trained merchandisers in customer care. A well sought customer service strategy is a must for milk processors to offer high quality service in order to outperform their less service - oriented competitors. Majority of the respondents agreed that they were able to identify dairy milk products using symbols and brand image. This indicates that, dairy milk processors had created brand awareness such that, customers were able to identify the milk brand mix on the shelves of retail outlets through brand recognition and by brand category.

Perceived service quality had statistically significant effect on satisfaction level and repeat purchase. The findings showed that, consumers of dairy milk products had a high rating of service quality offered to them by dairy milk processors and this increased their satisfaction level. Therefore, consumer satisfaction had improved because dairy milk processors had capitalized on consumer's empathy and the assurance that the product-service quality will be satisfactory and keep improving. This had led to enhanced performance in 
terms of improved profitability and firm image. Aykac, Aydn, Ates \& Cetin (2018) in the study "Effect of service quality on customer satisfaction \& customer loyalty in Marmara Hospital" indicates there was a positive and significant relationship between service quality and customer satisfaction and customer loyalty.

Dairy milk processors in Kenya must therefore strive to match and even exceed their customer's productservice quality with what customers expect. In Kenya today, over 15 million Kenyans have mobile phones. Dairy milk processors should liaise with the various mobile phone service providers to create a platform where the processors would showcase their various product positive attribute both through messages and digital marketing. This method is less costly, personalized and an effective way of creating brand awareness. The same platform can also be used to collect and respond to consumers' complaints. This is well supported by the Theory of Assimilation which states that, consumers make a sort of cognitive comparison between the expectations regarding the product and the product's perceived performance.

Perceived service quality is important for any processing firm to satisfy the needs of a consumer in order to remain competitive in the local market. Processors of dairy milk products should therefore introduce Quality of Service Monitoring System (QSMS) in order to assist in measuring quality of service provided to consumers. Therefore, perceived service quality is important for dairy milk processing firms to remain profitable and competitive in Kenya.

\section{Acknowledgments}

I am very grateful to my two supervisors, Dr. Ndung'u Kabare and Prof. Kenneth Wanjau for their guidance and support during this research period. Your invaluable advice, comments and constructive criticism is what makes this work what it is. May God Bless You All. I wish to acknowledge my PhD course work instructors as well as the administrative staff in the School of Business, Karatina University. To my colleagues, my friends and family members, your support and encouragement are invaluable.

\section{References}

Ateke, B. W., \& Kalu, S. E. (2016). Complaint Handling and Post-Complaint Satisfaction of Customers in Port Harcourt, Nigeria. International Journal of Research in Business Studies and Management, 3(12), 16-26.

Baiya, H. \& Kithinji, J. (2010). Transforming the Dairy Sector: Benefits from the Formalization of the Raw Milk Trade in Kenya. SITE Case Study. August 2010,www.valuechains.org/dyn/bds/813/sitedairycase.pdf.

Banerjee, N., \& Sah, S. (2012). A Comparative Study of Customers' Perceptions of Service Quality Dimensions between Public and Private Banks in India. International Journal of Business Administration, 3(5), 33-44. https://doi.org/10.5430/ijba.v3n5p33.

Benton, W. C., \& Maloni, M. (2005). The influence of power driven buyer/seller relationships on supply chain satisfaction. https://doi.org/10.1016/j.jom.2004.09.002

Brown, G.H. (1993). Brand Loyalty-Fact or Fiction.Advertising Age, 23, PP53-55

Bryman, A. (2007). Business Research Methods, (2nd ed.). New York: Oxford University Press.

Bryman, A. (2012). Social Research Methods (4th ed.). New York: Oxford University Press.

Caruana, A. (2002). Service Loyalty: The Effects of Service Quality and the Mediating role of Customer Satisfaction. European Journal of Marketing, 36(7), 811-828.

Chang, M. K. (2008). Predicting unethical behavior: A comparison of the theory ofreasoned action on the theory of planned behavior. Journal of Business Ethics, 17(16), 1825-1834.

Creswell, J. W. (2009). Research design: Qualitative, quantitative, and mixed methods approaches (3rd ed.). Thousand Oaks, CA: Sage Publications.

Creswell, J. W., \& Plano Clark, V. L. (2011). Designing and conducting mixed methods research (2nd ed.). Thousand Oaks, CA: Sage Publications. 
Dabholkar, P. A., Shepherd, C. D., \& Thorpe, D. (2000). A comprehensive framework for service quality: an investigation of critical conceptual and measurement issues through a longitudinal study. Journal of Retailing, 76(2), PP 139-173.

Davis, C. G., Dong, D., Blayney, D. P., \& Owens, A. (2010).An analysis of U.S Household Dairy Demand. Retrieved December, 2010, from www.ers.usda.gov/Briefing/Dairy/.

Dheepa.T, \& Karthikeyan.P. (2015). Customer's Perceived Service Quality of Departmental Stores; An Empirical Investigation. International Journal of Management Research \& Review, 5(7), 535-545.

Fonterra, (2017.).Innovation and technology products. Retrieved 15th March, 2017, http://www.fonterra.com/wps/wcm/connect/fonterracom/fonterra.com/Our+Business/Innovation+a nd+Tec hnology/Products/

Ghosh, P., Tripathi, V., \& Kumar, A. (2010). Customer expectations of store attributes: A study of organized retail outlets in India. Journal of Retail and Leisure Property, 9(1):75-87.

Grönroos, C. ( 2007). "Service Management and Marketing: Customer Management in Service Competition", (3rd Edit). London: John Wiley \& Sons Ltd.

Grönroos, C. (1994). Scientific Management to Service Management. International Journal of Service Industry Management, 5, (1), 5-20.

Gronroos, C. (2000). Service Management and Marketing: A Customer Relationship Approach. Chichester: Wiley \& Sons.

Grönroos, Christian. 2007. Service Management and Marketing, (3rd ed.). Delhi: John Wiley publishers.

Hemme, T., Alqaisi, O.A., \&Boelling, D. (2014). Benchmarking cost of Milk production in 46 Countries. Journal of Review on Global Economics, 3, 254-270.

Heskett,J., Jones,T.O.,Loveman, G., Sasser, W.E., \& Schlesinger,L.A. (2010). Putting the Service-Profit Chain to Work. Harvard Business Review, 72,(2), 453-461.

Hutchinsona, J., Laib, F., \& Wang, Y. (2009). Understanding the relationships of quality, value, equity, satisfaction, and behavioural intentions among golf travellers. International Journal of Tourism Management, 30(2), 298-308.

Jain, S. K., \& Gupta, G. (2004). Measuring Service Quality: Servqual vs. Servperf Scales. Vikalpa, 29, (2), 25-38. https://doi.org/10.1177/0256090920040203

Jap S.D., \& Anderson E. (2009). Testing a life-cycle theory of cooperative inter-organizational relationships: Movement across stages and performance. Management Science, 53(2), pp. 260-75

Jap, S. D., Manolis, C., \& Weitz, B. A. (1999). Relationship Quality and Buyer-Seller Interactions in Channels of Distribution. Journal of Business Research, 46, (3), 303-313. https://doi.org/10.1016/S01482963(98)00032-0.

Karanja, A. M. (2007). The dairy industry in Kenya: the post-liberalization agenda. International Journal of Economics, Commerce and Management, 5 (5), 23-35.

Kariuki, A. N. (2016). Influence of Product Diversification Drivers on Performance of Dairy Enterprises in Kenya. Unpublished Doctoral dissertation. Nairobi: Jomo Kenyatta University of Agriculture and Technology.

Kariuki, A. N., Iravo, M. A., \& Kihoro, J. M. (2015). Access to resources for product diversification and performance of informal dairy enterprises in Kenya. International Journal of Business and Commerce, 4, (8), PP 17-33.

Kariuki, A. N., Iravo, M. A., \& Kihoro, J. M. (2015). Value Addition and Performance of Informal Dairy Enterprises in Kenya: A Product Diversification Perspective. IOSR Journal of Business and Management, 17(9), 2319-7668. https://doi.org/10.9790/487X-17914049. 
Kenya Dairy Board. (2015).Activities within the Kenyan Dairy Industry and List of Processors. Nairobi: Government of Kenya.

Khosti, Z. S. (2016). Developing Service Quality for Lepistö Group Oy (Hintakaari). Theseus. Fi. http://www.theseus.fi/handle/10024/119155

Kiplang'at, M. J. (2015). A supply chain management prototype for milk in Kenya : case of Gakindu Dairy in Nyeri County. Retrieved from https://su-plus.strathmore.edu/handle/11071/4611

Kumar, A. A., \& Babu, S. (2014). Factors influencing consumer buying behavior with special reference to dairy products in Pondicherry state. International Monthly Refereed Journal of Research In Management \&Technology, 3, PP 65-73.

Kumar, B., \& Gogoi, M. (2004). Customer lifetime value approaches and best practice applications. Journal of Interactive Marketing Banner, 18, (3), 234-242.

Kumar, V., \&Bhagwat, Y. (2015). Regaining "lost" customers: the predictive power of first lifetime behavior, the reason for defection, and the nature of the win-back offer. Journal of Marketing, 79, PP 34-55.

Kumar, V., Batista, L., Maull, R., Shahrinaz, I., Yacob, Y., Hummida, D., \& Lindestad, B. (2011). The Impact of Operations Performance on Customer Loyalty. Service Science, 3(5), 158-171. https://doi.org/10.1287/serv.3.2.158

Kumari, K., Usmani, S., \& Husain, J. (2013). HR management practices and customer satisfaction: The mediating effect of effective supply chain management practice. Global Business and Management Research, 5, (2/3), PP137.

Mertens, D.M. (2010). Research and evaluation in education and psychology. Integrating diversity with quantitive, qualitative and mixed methods . London; UK: Sage publishers.

Mittal, V., Kumar, P., \& Tsiros, M. (2015). Attribute-level performance, satisfaction, and behavioral intentions over time: A consumption-system approach. Journal of Marketing, 63(2),88..https://miami.pure.elsevier.com/en/publications/attribute-level-performance-satisfactionand-behavioral-intention

Mutura, K. J., Nyairo, N., Mwangi, M., \& Wambugu, K. S. (2016). Analysis of Determinants of Vertical and Horizontal Integration among Smallholder Dairy Farmers in Lower Central Kenya. International Journal of Agricultural and Food Research (Vol. 5). https://doi.org/10.24102/ijafr.v5i1.596

Mwendwa, V. C. (2008). Strategic responses by Kenya Milk Processors to environmental challenges. Retrieved November, 2008, from http://erepository.uonbi.ac.ke/handle/11295/7965

Njagi, E. W. (2013). Factors affecting the distribution of dairy products: a case of Githunguri Dairy Farmers Cooperative Society Limited. Retrieved August 1, 2013, from http://irlibrary.ku.ac.ke/handle/123456789/6171

Njarui D., Nguluu, S. N., Mwangi, D. M., \& Keya, G. A.(2012) .Challenges in milk processing and marketing among dairies in the semi-arid tropical Kenya. Livestock Research for Rural Development,Vol.22, Nairobi, Kenya.

Njarui, G., Gatheru, M., Wambua, J., Nguluu, S., Mwangi, D. M. \& Keya, G. A. (2009). Dairy Cattle Value Chain Assessment: Characterization of Milk Production in Semi-Arid Kenya. KASAL Dairy Working Document 1. Nairobi, Kenya.

Nyariki D. M., \& Thirtle C. (2000). Technical innovation and farm productivity growth in dry land Africa: The effects of structural adjustment on smallholders in Kenya. Agrekon 39,(4), PP597-606.

Nyariki, D. M. (2009). Impacts of policy reforms on the livestock industry in Kenya: The case of the dairy sector. Livestock Research for Rural Development, 21(10).

Odero, J. A. (2017). Smallholder dairy production in Kenya; a review. Livestock Research for Rural Development 29 (7) 2017. Retrieved from http://www.Irrd.org//rrd29/7/atiw29139.html 
Odero-Wanga, D. A., Mulu-Mutuku, M. W., \& Ali-Olubandwa, A. (2013). Overcoming the Odds: Strategies Used By Women Entrepreneurs in Milk Microenterprises in Kenya. American Journal of Human Ecology, 2(2),PP60-66. https://doi.org/10.11634/216796221504311

Oliver R.L. (2009). "Satisfaction: A behavioral perspective on the consumer", 2nd ed. New York: M.E. Sharpe Inc.

Olorunniwa, F., Hsu, M.K., \& Udu, G.J. (2006). Service quality, customer satisfaction, and behavioural intentions in the service factory. Journal of Services Marketing, 20(1): 59-72.

Ozturkcan, S., Aydin, S., Ates, M., \& Tansel Cetin, A. (2009). Effects of Service Quality on Customer Satisfaction and Customer Loyalty. Retrieved March 19, 2009, from https://doi.org/10.2139/ssrn.1362601.

Parasuraman, A., Zeithaml, V. A., \& Berry, L. L. (1985). A conceptual model of service quality and its implications for future research. Journal of Marketing, Vol. 49, PP 41-50.

Parasuraman, A., Zeithaml, V. A., \& Berry, L. L. (1988). SERVQUAL: A multiple-item scale for measuring consumer perceptions of service quality. Journal of Retailing, 64,(1), PP12-40.

Roberts, J. (2003). The Manufacture of Corporate Social Responsibility: Constructing Corporate Sensibility. Organization Journal, 10(2), 249-265. https://doi.org/10.1177/1350508403010002004

Saunders, M. L., Lewis, P., \& Thornhill, A. (2009). Research Methods for Business Students, (5th ed.). Harlow: Pearson Education.

Spohrer, J., \& Maglio, P. P. (2008). The Emergence of Service Science: Toward Systematic Service Innovations to Accelerate Co-Creation of Value. Production and Operations Management, 17(3), 238-246. https://doi.org/10.3401/poms.1080.0027

Tseng, V., \& Seidman, E. (2007). A systems framework for understanding social settings. American Journal of Community Psychology, 39(3-4), 217-228. https://doi.org/10.1007/s10464-007-9101-8

Tuei, B. C. (2010). Milk Quality control and regulation in Dairy Production: A Case of Dairy Producers in Kikuyu Division, Kabete District, Central Province. African Association of Agricultural Economists, Cape Town, South Africa.

Wolfe, K., \& Best, M. (2005). Polk County Dairy Feasibility Analysis. Center for Agribusiness and Economic Development, Georgia, University of Georgia.

Wolfe, K., \& Shepherd, T. (2006a). Augusta Area On-Farm Milk Processing Feasibility Analysis. Center for Agribusiness and Economic Development, Georgia, University of Georgia.

Wolfe, K., \& Shepherd, T. (2006b). A Feasibility Analysis for On-Farm Bottling of Milk in Morgan County Georgia. Center for Agribusiness and Economic Development, Georgia, University of Georgia.

Wolfe, K., Escalante, C., \& McKissick, J. 2006. Market Analysis of Traditional, Grass Fed \& Organic Milk in Selected Markets. Center for Agribusiness and Economic Development, Georgia, University of Georgia.

Zeithaml, V. A., Bitner, M. J., \& Gremler, D. D. (2006). Services Marketing Integrating Customer Focus across the Firm. Boston: MA publisher. 